\title{
Identity and Role of Gender in the Relationship of Couple: A Generational Study on Stay in Marriage
}

\section{Anirian de los Ángeles Esquila Ambriz*, Susana Silvia Zarza Villegas, Gabriela Villafaña Montiely and Hans Oudhof Van Barneveld}

Universidad Autónoma del Estado de México, México

*Corresponding Author: Anirian de los Ángeles Esquila Ambriz, Universidad Autónoma del Estado de México, México.

Received: August 16, 2019; Published: September 30, 2019

DOI: $10.31080 /$ ASNE.2019.02.0110

\begin{abstract}
The purpose of this study was to analyse how gender identity and role in couples who stay married live. Participants were part of families of three inbred generations; five grandparents aged 70 and 89 years, six sets of parents aged between 47 and 73 years and three young couples aged between 22 and 33 years.

This according to the results of this investigation it was found that the first and third generation show marked similarities in the fact that young people seem to repeat familiar patterns to remain in traditional roles shows that the man works and the woman devoted to home and children Contrary to what might be expected today.

The three generations refer disagreement in the management of male and female roles socially established by both genders. Finally the young generation is in internal conflict, not knowing how to defend their interests without involving a separation. We conclude that the family tradition, social image, resignation and personal safety are elements in the decision to stay married in three generations.
\end{abstract}

Keywords: Gender Identity; Gender Role; Relationship And Marriage

\section{Introduction}

At present the human couple shows with some changes that have to do with the fact that some women already have the possibility of without depending economically on its couples, with what a radical difference is marked in the form as men and women are related, so that they are now less ready to tolerate aggressions and lacking in love, propitiating with it a major divorces quantity, being the woman the first one in requesting it [1].

If there are checked the statistics of Marriages and Divorces provided by the National Institute of Statistics and Geography (2011) it is had that in $195050.8 \%$ of the whole of the Mexican population she was married and $0.7 \%$ was divorced, in 1993 , for every 100 marital unions five divorces happened; in 2011 this relation increased 16 for every 100, as it is possible to observe the separations tendency for generation it is on the increase and that of marriages has diminished.

Undoubtedly, the matrimonial tie is influenced by the whole series of elements that affect its permanence. The existence of historical, economic and cultural changes they have provoked that the commitment and the stability are modified [2], but: Down what circumstances have managed to last the marriages? And: what is the reason for which the young people at present decides remain married? in an epoch in which there is had the entire freedom of getting divorced if there is no entire understanding.

To answer to these questions [3] it recounts that the increasing incidence of separations and of divorces cannot be interpreted as an indicator of "marital unhappiness" since couples that are unhappy can prefer to remain close because in spite of everything they believe in the marriage, because they worry for the emotional effects associated with the rupture, or because they want to remain joined to give to its children a "familiar" hearth, the reasons for which the couples in this epoch remain in its marriage can be diverse, what yes is notable is its desire to keep on fighting because they are sure of it not because someone forces them to do it.

The daily reality shows that the couple is a challenge and that it is necessary to learn to realize changes and to use the energy to be 
more one himself and to be reconstructed in projects that nourish and more inscrutable generate ties. To construct the couple and the affective tie from a historical moment, in which the women, are less enslaved to the maternity, and where the ideal couple and the love tend to disappear so rapidly as consumption objects is not simple.

It is necessary to admit that in the current couples there exist difficulties of realizing more lasting and significant meetings from the personal, familiar thing, but also from the social thing for the ideological conditionings and of genre that they shut up in invisible jails to men and women, but in spite of the difficulties it mentions [4] the divorce must not be seen like the only exit to the problems that in the marriage arise because in most cases the divorce, by no means it means a solution, but it is equivalent to the incapability to solve a situation of interior conflict, for which the divorce does not avoid the repetition of the same conflict in the second, third, fourth or umpteenth marriage either.

The previous thing leads to thinking that couple relation man - woman, can be considered to be one of the most gratifying experiences but at the same time it can turn into one of the most complex interpersonal relations if there cannot manage the elements that enter game at the time of beginning it, an example of it there are the called rolls of genre that are usually very important in a relation.

These positions (rolls) are capable of stipulating how there is administered the hearth, who it is the one that takes the main decisions and even, up to determining the health of the relation itself. It is very strange that the couples take to consideration the rolls division during the engagement, in most cases, the genre rolls are not defined completely even after the marriage. At the beginning of a relation, the couples tend to do everything together and rarely they divide the tasks, which can represent complications once it is decided to share the life together.

Some men and women grow in traditional hearths and hope that the hearths that now they are forming should continue the same pattern. For example, it is very common that the men feel that the woman in the relation must be a person in charge of cooking, of cleaning and of raising the children and in case of the women who are used to the traditional rolls, hope that the man should have or should gain enough money and should pay for everything, in addition to whom he arranges the breakdowns in the house and takes the important and difficult decisions. When two persons do not agree with these functions, it is a fact that will produce a conflict to itself and it can put in risk the stability of the relation provoking with it inclusive the separation.
On this matter, Fonseca and Farmer (2008) mention that the changes that are appearing at present lead to thinking about a rolls redefinition, understanding that to re-define the feminine roll implies a redefinition of the masculine roll and in this sense, many men have fallen behind, or have turned out to be forced to adapt themselves to new rolls, therefore the social role that the woman develops at present, already is at home or taking part in the public ambience it has effects not only in itself but also in the male because in accordance with Bramble (2008) this creates a subjective uncertainty before the places "masculine and "feminine" that begin stopping being so clear.

Given the previous thing, this investigation studies the relation of couple and marriage from two important aspects of the Genre, the Identity of genre and the roll of genre which are considered to be the result of a process of socialization that uses of the social constructions of "being a woman" and "to be a man", to prescribe structural ways of feeling, of thinking, of doing and of recognizing / based on feminine and masculine scripts, using speeches and practices that they are repeated constantly in the everyday life to create the illusion of an objective and inevitable reality of the masculine and feminine subjectivities.

The interest to realize this study in three generations departed from the assumption about which the current young couples cannot be understood without seeing what has happened and what they have left the couples nearest to these to them, in terms of continuity, rupture, transition or change.

The generation is considered to be by [5] in a sociological sense as the set of that (expert) who share a position with regard to the relations of descent (or vice versa) that is to say, in accordance with the biological and cultural succession.

In the same way, the intergenerational studies are a route to understand the social change because it is there where the aspirations grow from one generation to other one. The realized investigations have gone beyond the description and have incurred the aspects related to the changes in the roles and auto perception of the individuals themselves.

There exist diverse generational studies between which they emphasize the Gentleman's investigation (2001) in grandmothers, mothers and granddaughters which focused only in wives of three generations as well as the study of Bramble (2008) realized in two generations of men and women to visualize changes in the traditional relations. In this case to be able to analyze how men and women live through its identity and genre roll inside an equal relation was 
chosen for studying couples that remain married of three consanguineous generations doing main emphasis on the young people.

\section{Methods}

General target

- To analyze how the identity and roll of genre one lives in couples that remain married of three consanguineous generations.

\section{Specific target}

- To identify how the generation of young people is living through its masculinity and femininity

\section{Type of study}

It is an investigation of qualitative cut. [6] consider in a wide sense, the qualitative investigation as that one that produces descriptive information taking into consideration the proper words of the persons, spoken or written, and the observable conduct.

In accordance with the investigation level, that is to say, the grade of depth with which a phenomenon or object of study is tackled, the investigation is framed of type Descriptiva, because the descriptive studies think about how to specify the most important properties of persons, groups, communities, entities, organizations or any other phenomenon that is submitted to an analysis process. According to Méndez (2001), "the descriptive study identifies typical of the universe of investigation, points out forms of conduct and attitudes, establishes concrete behaviors, discovers, verifies and analyzes the investigation variables" (p. 137).

\section{Definition of categories}

For the present study two main categories were tackled:

- Identity of Genre and Roll of Genre

- Relation of Couple and marriage

From these two and as soon as the results were obtained, created seven subcategories to present the results: Attitude before its masculinity and femininity, attitude before its roll of genre, dynamics at home, parenthood, maternity, handling of the conflict and attitude before the divorce.

\section{Conceptual definition}

\section{- Identity of genre and roll of genre}

In accordance with Bleichmar (1985) the genre identity is the scheme I design affectively more primary, conscious and unconscious, from the belonging to a sex and not to other. It is established more or less at the same age in which the creature acquires the language ( 2 - 3 years), is previous to its knowledge of the anato- mical difference between the sexes. As soon as the genre identity was established, when the prepubescent one is known and takes up office as belonging to the group of the masculine thing or of the feminine thing. This one identity turns into a filter for which all its experiences happen.

As for genre roll it is said that it is intimately associated with the generic identity and with the personality in its entirety, it is a psychological phenomenon that expresses the particular, proper way of every person of interpreting and of re-meaning the social sexual patterns [7].

\section{- Relation of couple and Marriage}

He considers two persons proceeding from different families, generally of different genre, which they decide to link affectively to share a common project, what includes to rest and to exchange important aspects mutually, in a proper space that it excludes to others but that they interact with the social environment (proper making).

As soon as the couple relation was formed it is possible to speak about marriage that in accordance with Bramble (2008) is considered to be the first cell of the social order, it presents itself as the point of common arrival for the majority and it is recognized like normative route of acquisition of status, it represents the suitable framing so that the woman and the man fulfil the femininity and assumed masculinity.

\section{Operational definition}

The Identity of genre and the roll of genre that each one assumes obtained by means of an interview semi structured that was designed especially for this study, likewise there was used the Scale of Identity of Genre (Bramble, 2008) to obtain aspects of the masculinity and femininity in the relation of young couples.

For the relation of couple and marriage there was considered the time that they have joined as well as the motives for which they have decided to continue, this information was obtained by means of the interview designed for this investigation.

\section{Participants}

The form of reception was intentional, using the skill "snowball", which consists of identifying possible participants by means of the inquiry with nearby persons and achieving that they present themselves other possible participants (Taylor and Bogdan, 1987). The inclusion characteristics consisted of the fact that had to be young couples that were provided with its parents and grandparents to 
expire with the consanguinity needed from three generations and that were remaining married or in free union with at least a son.

For this study one worked with couples of 3 consanguineous generations, of which four grandmothers and a grandfather took part with ages between 70 and 89 years, the second generation was represented by six parents couples with ages between 47 and 73 years and three young people couples shaped the third generation with ages between 22 and 33 years. These couples in general count at a basic education level and live in towns located in the surroundings of Toluca.

\section{Skills and/or used instruments}

For the present study, the investigation was realized across two means:

1. He interviews semi structured and B) Scale of Identity of Genre (EIDGEN)

2. He interviews semi structured: This type of interview facilitated the investigation because one was provided with pre-established questions, which helped to maintain the interview focused particularly on the topics of interest and it was possible to provide to the informant the space and the sufficient freedom to express itself (Tarrés, 2001). The interview guide has a content validity from the evaluation expressed by judges expert in the matter.

It is important to mention than to tackle the interest categories: Identity of genre and roll of genre as well as the relation of couple and marriage, the interview guide included subject-matters relative to the Family of origin and couple Relation like main dimensions, in the origin family paragraph there were tackled aspects of its familiar dynamics, parents, brothers, sexual identification, as well as the authority exercise. As for the couple relation there was obtained information regarding the election of couple, perception of the marriage and couple, conflicts of couple, parenthood / maternity as well as aspects of the dynamics of the relation of couple.

1. Scale of Identity of Genre (EIDGEN, Bramble, 2012): For the purpose of identifying how they are living through its masculinity and femininity the generation of young people one made use of a scale prepared by Bramble (2012) whose target is to investigate characteristics relative to the Identity of Genre (masculinity and femininity) in 17-yearold men and women from now on; from words that there associate with the term woman and the term man.
The scale contains a series of 25 questions type Likert, with five answer options: Much in agreement, of agreement, I not agree not even disagreement, in disagreement and much in disagreement. It is provided with three dimensions: Process of change, conservative Speech and Progressive Speech. The application can be individual or group with the possibility of being auto applicable.

\section{Procedure}

The taking part couples were contacted for the first time to announce the ends of the investigation and the form of work, dislocated a bone the confidentiality and seriousness of the information provided to guarantee the confidence and the interest in the participation and power of this form to pass to the first formal appointment.

Once they accepted they were visited in its hearth to explain the form of work, agreeing on the dates and on the suitable times.

Likewise there was obtained the general and socioeconomic information of the participants and only in case of the generation of young people there was considered to be suitable the application of the Scale of Identity of Genre (EIDGEN, Bramble, 2012) to reinforce the obtained information of the interview and to reach the established target regarding the investigation of the form in which the young people is living through its masculinity and femininity to the interior of a relation of couple. The instruments were considered to be only a support since in the interview it was possible to obtain all the information needed for this investigation.

Later the interviews of an individual way were carried out, having from 4 to 5 meetings of an hour of duration with each one, these were realized in the house of the participants for major serviceability.

As soon as the interviews were concluded one proceeded with the qualification of the instrument applied to the generation of young people in accordance with the manual to obtain excellent information, likewise the information provided by the informants was transcribed literally, once concluded this phase separated the information in accordance with the interest categories: Identity of genre and roll of genre as well as relation of couple and marriage. Later the information was purified to prepare three pictures like which only it was remaining one for generation and which was including to both categories for major clarity, one added one more column to the picture of the generation of young people regarding the results of the instrument. 
For the general information they present in the same way one to themselves for generation with such aspects like the age, occupation, years of married, number of children and schooling of every participant. As soon as the results were obtained one proceeded with the analysis of the information which is explained to detail further on.

\section{Results}

General information of the participants On the information sociodemographic of the Generation of Grandparents it is possible to observe that mostly they are the grandmothers who took part in the investigation be already because its husband died or he endures some illness that disabled it. In this generation to be able to obtain the results of the lacking males it was considered to be the reference that each of the women did with regard to its couple (Table 1).
In case of the Generation of Parents (I square 2) it highlights that 6 couples are married for the civil and religious law as its parents. One finds that both the man and the woman work, in case of the women, apart from being housewives they devote themselves to sell some product for its account, work the field or in some company. The number of children diminishes in comparison to that of its parents.

In the generation of young people he emphasizes the following thing (Table 3):

They take a little time of married (from 9 months until 2 years). Two of the couples live in free union and one of them is married for the civil one, recounting that it was necessary to marry to obtain the medical insurance. The number of children diminishes signifi-

\begin{tabular}{|l|c|c|c|c|c|c|c|}
\hline Generation & Parentesco & Age & Occupation & Married Years & Edo. Civil & Schooling & Children \\
\hline \multirow{4}{*}{ Grandparents } & Peter's grandmother & 81 & Home & 66 & Married & No & 11 \\
\cline { 2 - 8 } & Enrique's grandmother & 70 & Home & 31 & Married & No \\
\cline { 2 - 8 } & Pepe's grandfather & 89 & Retired & 63 & Married & Truncated primary & 7 \\
\cline { 2 - 8 } & Pepe's grandmother & 86 & Home & 63 & Married & Primary & 7 \\
\cline { 2 - 8 } & Berenice's grandmother & 86 & Home & 62 & Married & Truncated primary & 12 \\
\hline
\end{tabular}

Table 1: General information of the Grandparents.

\begin{tabular}{|c|c|c|c|c|c|c|c|}
\hline Generation & Parentesco & Age & Occupation & Years Of Casados & Edo. Civil & Schooling & Children \\
\hline \multirow{12}{*}{ Parents } & Peter's dad & 53 & Decorator & 31 & Married & Vocational & 3 \\
\hline & Pedro's mom & 49 & Home/sale & 31 & Married & Primary & 3 \\
\hline & Juana's dad & 48 & Contractor & 31 & Married & Secondary & 3 \\
\hline & Joan's mom & 47 & Educational Promoter & 30 & Married & Secondary & 3 \\
\hline & Enrique's dad & 50 & Worker & 28 & Married & High school & 3 \\
\hline & $\begin{array}{l}\text { Enrique's } \\
\text { mom }\end{array}$ & 47 & $\begin{array}{c}\text { Workers/home work- } \\
\text { ers }\end{array}$ & 28 & Married & Secondary & 3 \\
\hline & Karla's dad & 66 & Pensioner/field & 31 & Married & Secondary & 3 \\
\hline & Karla's mom & 53 & Home/Field & 30 & Married & Technical Career & 3 \\
\hline & Pepe's Dad & 68 & Trader & 45 & Married & Primary & 4 \\
\hline & Pepe's mom & 66 & Home/trade & 46 & Married & $\begin{array}{c}\text { Truncated } \\
\text { primary }\end{array}$ & 4 \\
\hline & $\begin{array}{l}\text { Berenice's } \\
\quad \text { dad }\end{array}$ & 73 & Peasant & 36 & Married & No & 4 \\
\hline & $\begin{array}{l}\text { Berenice's } \\
\text { mom }\end{array}$ & 51 & Home/trade & 36 & Married & No & 4 \\
\hline
\end{tabular}

Table 2: General information of the Parents. 
cantly compared to its parents and grandparents, has the only one and glides to have maximum two. Its schooling level is a top way and a half. They expressed for proper decision non-keeping on studying in spite of being provided with the opportunity to do it. The men have good work places. The only one of the women has technical career but it does not work. Three participants were working before marrying but they stopped doing it once they married to devote themselves to the hearth and children exclusively.

\section{Description of the Results}

Generation of grandparents

There is observed acceptance of its identity of genre on the part of men and women, although the women prove to be nonconformist with the roll that they redeem they do not express it. A void approach existed with the children on the part of the males which was normal for them because they were dedicated to the work

\begin{tabular}{|l|c|c|c|c|c|c|c|}
\hline Generation & Number & Age & Occupation & Years Of Casados & Edo. Civil & Schooling & Children \\
\hline \multirow{4}{*}{ Nietos/ Young } & Juana & 25 & Home & 2 & Civil married & High school & 1 \\
\cline { 2 - 8 } & Pedro & 26 & Programmer & 2 & Civil married & High school \\
\cline { 2 - 8 } & Enrique & 28 & Trader & 9 Months & Free union & Secondary & 1 \\
\cline { 2 - 8 } & Karla & 22 & Home/sale & 10 Months & Free Union & Secondary & 1 \\
\cline { 2 - 8 } & Pepe & 33 & Trader & 1.2 & Free/Separate Union & Truncated high school & 1 \\
\cline { 2 - 8 } & Berenice & 32 & Home & 1.2 & Free/Separate Union & Technical career & 1 \\
\hline
\end{tabular}

Table 3: General information of the Children.

what turned them into providers. There is clear the position of domination and submission, where the main authority relapses into the male. The permanence in its relation is justified in the resignation on the part of the woman and in the satisfaction on the part of the male, the divorce was not an option for both (Table 4).

\section{Generation of parents}

It is clear that the males accept its identity and genre roll, in what it refers to the women, they accept its identity more not its roll of genre for which they rebel to be able to devote themselves to something more than to the hearth. The males want to be closer

\begin{tabular}{|c|c|c|c|}
\hline \multicolumn{3}{|r|}{ Gender Identity And Rol } & Couple And Matrimony Relationship \\
\hline \multirow{2}{*}{$\begin{array}{l}\text { Attitude to masculinity/ } \\
\text { femininity }\end{array}$} & $\mathrm{H}$ & $\begin{array}{l}\text { They assume the characteristics considered socially } \\
\text { as the son's own: the law, entrepreneurship, power, } \\
\text { command, limits, action. }\end{array}$ & \multirow{14}{*}{$\begin{array}{l}\text { Satisfaction was observed on the part of males } \\
\text { and instead resignation in women with regard } \\
\text { to their maritalrelationship. } \\
\text { Women play a passive role and men play a } \\
\text { dominant role. }\end{array}$} \\
\hline & M & $\begin{array}{l}\text { They assume the characteristics considered socially } \\
\text { as the woman's own: nutrition, shelter, willingness to } \\
\text { listen and for embrace. }\end{array}$ & \\
\hline \multirow{2}{*}{$\begin{array}{l}\text { Attitude to her role as a } \\
\text { gender }\end{array}$} & $\mathrm{H}$ & Conform to the role they play & \\
\hline & M & $\begin{array}{l}\text { They do not accept the role they play but do not ex- } \\
\text { press it }\end{array}$ & \\
\hline \multirow{2}{*}{ Home dynamics } & $\mathrm{H}$ & Exclusively suppliers & \\
\hline & M & Dedicated to home and children & \\
\hline \multirow[b]{2}{*}{ Paternity } & $\mathrm{H}$ & Absent parents, wanted sons & \\
\hline & M & $\begin{array}{l}\text { They had no problem with the absence of the father, } \\
\text { there was no preference in the sex of the children. }\end{array}$ & \\
\hline \multirow[t]{2}{*}{ Maternity } & $\mathrm{H}$ & $\begin{array}{l}\text { They felt it was the mother's duty to dedicate herself } \\
\text { to her children }\end{array}$ & \\
\hline & M & Proud to be the ones who raised their children & \\
\hline \multirow[t]{2}{*}{ Conflict management } & $\mathrm{H}$ & $\begin{array}{l}\text { Physical, verbal and psychological violence towards } \\
\text { your partner and children. }\end{array}$ & \\
\hline & M & They didn't defend themselves, cry and shut up. & \\
\hline \multirow[t]{2}{*}{ Attitude to divorce } & $\mathrm{H}$ & Separation is not an option & \\
\hline & M & Separation is not an option & \\
\hline
\end{tabular}

Table 4: Identity of genre, roll of genre and typical of the relation of couple of men and women joined for more than 50 years (Grandparents). 


\begin{tabular}{|c|c|c|c|}
\hline \multicolumn{3}{|r|}{ Gender Identity And Rol } & \multirow{4}{*}{$\begin{array}{l}\text { Couple Relationship } \\
\text { Satisfaction was observed } \\
\text { on the part of males and in- } \\
\text { stead dissatisfaction on the } \\
\text { part of women with regard } \\
\text { to their marital relation- } \\
\text { shin }\end{array}$} \\
\hline \multirow[t]{2}{*}{$\begin{array}{l}\text { Attitude to masculinity/ } \\
\text { femininity }\end{array}$} & $\mathrm{H}$ & $\begin{array}{l}\text { They assume the characteristics considered socially as the son's } \\
\text { own: the law, entrepreneurship, power, command, limits, action. }\end{array}$ & \\
\hline & M & $\begin{array}{l}\text { They assume the characteristics considered socially as the woman's } \\
\text { own: nutrition, shelter, willingness to listen and for embrace. }\end{array}$ & \\
\hline \multirow{2}{*}{$\begin{array}{l}\text { Attitude to her role as a } \\
\text { gender }\end{array}$} & $\mathrm{H}$ & Conform to the role they play & \\
\hline & M & Disgust with their role, they rebel to be able to work & \multirow{3}{*}{$\begin{array}{l}\text { The woman subtly } \\
\text { believes, the male is still } \\
\text { searching for his dominant } \\
\text { role. }\end{array}$} \\
\hline \multirow[t]{2}{*}{ Home dynamics } & $\mathrm{H}$ & Increased financial contribution at home and little help at home & \\
\hline & M & $\begin{array}{l}\text { Dedicated to the home and children in addition to contributing fi- } \\
\text { nancially. }\end{array}$ & \\
\hline \multirow[t]{2}{*}{ Paternity } & $\mathrm{H}$ & Absent parents, there is no preference in the sex of children. & \multirow{8}{*}{ Women seek equality } \\
\hline & M & $\begin{array}{l}\text { They wanted greater closeness of the father to their children, there } \\
\text { is no preference regarding the sex of the children }\end{array}$ & \\
\hline \multirow[t]{2}{*}{ Maternity } & $\mathrm{H}$ & $\begin{array}{l}\text { They wanted to get close to their children, but the work absorbed } \\
\text { them. }\end{array}$ & \\
\hline & M & Proud to be the ones who raised their children & \\
\hline \multirow[t]{2}{*}{ Conflict management } & $\mathrm{H}$ & $\begin{array}{l}\text { Verbal violence towards your partner only at the beginning of the } \\
\text { relationship. }\end{array}$ & \\
\hline & M & They were shutting up to "not make it bigger." & \\
\hline \multirow[t]{2}{*}{ Attitude to divorce } & $\mathrm{H}$ & Separation is not an option & \\
\hline & M & Separation is not an option & \\
\hline
\end{tabular}

Table 5: Identity of genre, roll of genre and typical of the relation of couple of men and women joined for more than 25 years (Parents).

to its children but the work keeps on absorbing them; the woman begins to think and to support economically. Although the male begins taking into consideration its couple it continues in search of its domineering role before this, the woman proves to be unsatisfied of its marital relation but nevertheless the separation is not an option for both (Table 5).

\section{Generation of children}

In what it refers to the young people the males accept its identity and genre roll while the women accept its identity but they are not to taste with the housewives' roll, they demand to be taken into consideration and think openly. The males are the only ones that reach port economically to the hearth in addition to which they try to interfere in the domestic works which costs them a lot of work. Although the males have a major approach with its children the women do not give them the sufficient space so that they do it, it is important to highlight that both men and women have exercised physical and verbal violence towards its couple.

The men seem to be satisfied by its relation on the other hand the women remain for commitment, it was notable that although the male strains for considering its couple to be this one keeps on thinking about how to have a domineering role. Although for the males the separation is not seen like an option while for the women yes, one of the couples chose to separate being the woman initially who took the decision to separate, finally the male accepted.

In what it refers to the instrument, it was observed that both men and women try to advance, its desire is to accept the new ways of being related between men and women but it is difficult to them to assume it. Although its speech should be slightly traditional in practice the opposite is observed (Table 6).

It is necessary to highlight that the males of three generations proved to be satisfied with the marital relation while the women were saying the opposite, dissent being able to be observed on the part of the woman with its roll of housewife and exclusive minder of the children.

In three generations the man thinks about how to continue with its domineering role although in the second and third generation the participation and demand of the women turns it a little more difficult. In no generation the separation was an option although a young people couple separated. Although there was observed major womens participation in the second and third generation the equality between men and women has not been achieved. 


\begin{tabular}{|c|c|c|c|c|}
\hline \multicolumn{3}{|l|}{ Gender Identity And Rol } & \multirow{3}{*}{$\begin{array}{l}\text { Couple Relationship } \\
\text { Satisfaction was observed } \\
\text { on the part of males and } \\
\text { instead commitment on } \\
\text { the part of women to } \\
\text { their marital relationship. } \\
\text { The woman thinks open- } \\
\text { ly, the male wants to have } \\
\text { a dominant role. }\end{array}$} & \multirow{3}{*}{$\begin{array}{l}\text { Eidgen Results } \\
\text { Men and women agreed on } \\
\text { the results: } \\
\text {-Low level of resistance to } \\
\text { change }\end{array}$} \\
\hline \multirow[t]{2}{*}{$\begin{array}{l}\text { Attitude to hisintegrity/ } \\
\text { femininity }\end{array}$} & $\mathrm{H}$ & $\begin{array}{l}\text { They assume the characteristics considered } \\
\text { socially as the son's own: the law, entrepre- } \\
\text { neurship, power, command, limits, action. }\end{array}$ & & \\
\hline & M & $\begin{array}{l}\text { They assume the characteristics considered } \\
\text { socially as the woman's own: nutrition, shel- } \\
\text { ter, willingness to listen and for embrace. }\end{array}$ & & \\
\hline \multirow{2}{*}{$\begin{array}{l}\text { Attitude to her role as a } \\
\text { gender }\end{array}$} & $\mathrm{H}$ & Conform to the role they play & & \multirow{12}{*}{$\begin{array}{l}\text {-Low level of conservative } \\
\text { speech } \\
\text {-High level of progressive } \\
\text { discourse }\end{array}$} \\
\hline & M & $\begin{array}{l}\text { They reject their role but do not express it } \\
\text { openly. }\end{array}$ & Women seek equality & \\
\hline \multirow[t]{2}{*}{ Home dynamics } & $\mathrm{H}$ & $\begin{array}{l}\text { Total financial contribution at home and try } \\
\text { to get involved in domestic work }\end{array}$ & & \\
\hline & M & $\begin{array}{l}\text { Dedicated to the home and children but also } \\
\text { have an opinion and demand to be taken into } \\
\text { account }\end{array}$ & & \\
\hline \multirow[t]{2}{*}{ Paternity } & $\mathrm{H}$ & $\begin{array}{l}\text { They try to get more involved with their chil- } \\
\text { dren }\end{array}$ & & \\
\hline & M & $\begin{array}{l}\text { They find it difficult to allow the parent's } \\
\text { closeness to their children, there is no prefer- } \\
\text { ence regarding the sex of the children }\end{array}$ & & \\
\hline \multirow[t]{2}{*}{ Maternity } & $\mathrm{H}$ & $\begin{array}{l}\text { They want to get involved in their children's } \\
\text { education }\end{array}$ & & \\
\hline & M & $\begin{array}{l}\text { They are weighed on maternal work and } \\
\text { want help from their partner }\end{array}$ & & \\
\hline \multirow[t]{2}{*}{ Conflict management } & $\mathrm{H}$ & $\begin{array}{l}\text { They have exercised physical and verbal vio- } \\
\text { lence against their partner }\end{array}$ & & \\
\hline & M & $\begin{array}{l}\text { They have exercised physical and verbal vio- } \\
\text { lence against their partner }\end{array}$ & & \\
\hline \multirow[t]{2}{*}{ Attitude to divorce } & $\mathrm{H}$ & Separation is not an option & & \\
\hline & M & See separation as an option & & \\
\hline
\end{tabular}

Table 6: Identity of genre, roll of genre and typical of the relation of couple of young men and women (Children).

\section{Analysis of results}

I. Identity and roll of genre in couples of Grandparents, Parents and children

Across the time there have happened changes that have modified the genre rolls and that have achieved that the woman conquers new spaces, such as the insertion of the woman to the labor world, the revolution of the contraceptive pill, the right to vote and the biggest access to education. In spite of these advances it is still possible to see that bosses take place transmitted from generation to generation and that they contain marked genre differences, even in persons who maintain a speech of equality (Stein, 2001).
The traditional roles of the man and of the woman in the family were clearly delimited in three generations, that of the first one like provider of the resources of the hearth and main authority, and that of the second one like person in charge of the house and of the children. This was observed in the fact that the woman not externaba its dissents for fear, was proving to be resigned more not satisfied with its role to be redeemed, the fact that he was not speaking or complaining about through what he was living it was not meaning that inside her courage did not exist, the wives of the first and third generation were proving to be angry with themselves since only they devote themselves to the hearth and those of the second generation work and take care of its family like result of its insistence in being taken into consideration. 
It was observed that the familiar headquarters relapse principally into the males like result of the biggest contribution of the economic income on the part of these, as well as in its aptitude to solve matters of the public ambience. The predominant histories of these couples accentuate the fact that the women can only think in aspects related to the upbringing and the care of the children, although in the second and third generation the women strain for thinking and the men say to take into consideration its couples. One of the explanations that they provide to justify the existence of the masculine headquarters in the hearth is based on the familiar tradition that one has come observing across several generations.

The previous thing is confirmed on having thought in this investigation that in three generations the social stereotypes are supported about the masculine and feminine rolls, therefore the attributed characteristics transgeneracionalmente show to the man as provider while to the woman dedicated for the attention of the hearth and care of the children [8].

This aspect turns out to be more marked in the first generation where the woman prefers to maintain the silence and last before ending with its family since the internal load has a lot of weight in her ("less now I will separate, because what they are going to think of me" Pedro's Grandmother). One be evident how the phenomenon of the dependence fond principally of the women, for they be the components of the couple that accept resigned the conditions of the men, although accumulating frustrations, resentments and dissatisfactions.

The previous thing can owe to the recounted for [9], who mentions that the feminine thing refers to such epithets as subjectively, intuitively, passively, tenderly, sensitively, docile, receptively, empático, dependently, emotionally and conservative, which proposes that the mind of the women can receive in major measurement the relations and the feelings, having under its basic responsibility, the care of others and the fact of joining more than of separating. To understand how it is that these features have been adopted by the women the proposed is tackled by Burín (in Burín and Bleichmar, 1996) the one who affirms that from the Industrial Revolution in the western countries there were started two spheres of production and social representation as it they are the servant and the extra servant. The control of the family was assigned to the woman inside the house by means of the regularization of the emotions of the children and the men, for what was centring on this work and using of her to guarantee the achievement of its femininity and on the other hand the man was delegated by the responsibility of providing its family.
To expire in a complete way with these requisites of the femininity and masculinity they guarantee to the man and to the woman a place and a role inside the patriarchal culture and this way the characters remain definite and of thinking needed so that the women and men should exercise the genre rolls specially feminine and masculine that have been assigned to them [10]. The previous thing is confirmed on having thought that in three generations so much men and women keep on adopting the rolls traditionally established and mentioned in advance.

It is considered then that the system sex / genre [11], like a system of representation that assigns meaning (identity, value, prestige, place in the kinship structure, status in the social hierarchy) to the individuals inside the society, is still current in the participants of the study since it is observed that both it grants certain power to men and to women; the male in its macho position and the woman like mother and housewife manage to place themselves and be recognized inside the society.

Before this situation from the psychoanalysis [12] he thinks that the new thing a strange product is to the unconscious one therefore the compulsion to the repetition infiltrates into three generations. This is due to the fact that the subjective transformations that there implies the transition of the traditional forms to the not traditional ones are carried out across a considerable psychic effort which has not turned out to be reflected in any of the generations, perhaps because it has been more comfortable for them to continue in this position, since the energy that needs the development of the critical attitude that is needed is considerable, since it implies the processes of questioning the models, ideals and traditional customs, and the imagination and implementation of new manners of being in couple. In this aspect it is observed that, in the third generation, although the man in some moment has supported its couple in the domestic works and with its children, it finds it hard to him work to do modifications in its roll. "I like helping him, but only when I am of good not because she sends me, (Pepe)".

Although in the second generation it highlights the stock holding of the woman, the males do not agree with that work but they accept it and in spite of recognizing the efforts of its wives do not show it which owes perhaps to what [13] mentions, on having said that when the women are capable of being supported economically them and to its children they stimulate its independence sense, but simultaneously they erode the image that the men have of themselves; this condition was expressed by the only taking part male of the generation of grandparents (Pepe's Grandfather) on having criticized openly the women of now that they want "to be liberated", 
mentioning that neglect its family and have got lost the respect to themselves, because they even fall down in the infidelity.

\section{Couple relation}

The finds in this investigation indicate that the results are very similar to the obtained ones in the work of Bramble (2008). It highlights that in three generations both men and women in its feeling of children, lived with a paternal figure that was appearing like provider, like authority, and the daughters, with a feminine figure of mother dedicated to the hearth and children.

Principally in the first and third generation, one finds that grandparents and children tried with a major premeditation to safeguard these places; nevertheless, from the change of social practices in that the occupation of both spouses begins suffering modifications, one would wait for some change principally in the young people, which is not like that, these changes turn out to be reflected recently in the generation of parents, since the young people seems to repeat patterns and to be supported in the traditional roles, the man works and the woman devotes herself to the hearth and children but with one more attitude of conviction or expediency that of resignation as it happened in the generation of grandparents.

For his part the young woman has the desire to work, to realize another type of activities different from those of the hearth and the man of interfering more with its children and supporting at home, but it has not remained any more that in a mere desire and like a visualization to future since the cultural history that they bring with it exceeds them.

It is as well as it is observed that in three generations the fact that the couple should remain close it is important. Specially this fact weighs more in the third generation because the young people says to be supported in its relation because they do not have the support of its parents in addition to which in its family it is not well seen that a couple separates. Opposite of what should be expected, in the generation of grandparents the women continued with its relation for proper decision (in spite of having the support of its parents for separase), since "what they will say" was weighing more in them. On the other hand in the generation of young people, the mother is who motivates to continue with the relation, "I am not going to withstand my daughters, they are not going to be going and to coming, must fight for its marriage (mom of Karla)" with which observes that the young people does not have proper decision and feels pressed for the familiar tradition.
The maternal figure turns out to be important since in accordance with [14], it is the mother who acts as transmitting main, after there delimit from her own generic identity what there are and a man and a woman do. It is possible to observe in the participants, that already in the routine character they were involving so much men as women in the domestic activities and the daughters of these had some gainful occupation. Transmitting so the rolls can be distributed in both genres, which in the generation of young people is reflected like internal and social conflict. Conflict because there is brought by it the image of a mother dedicated to the hearth and for other that is the same mother the one that sows the bases of the study and work in the women and the domestic support in the men. Giving like result that the genre allocation is not clearly exhibited in the third generation. The previous thing leads to saying that the third generation is in Transition towards the new social forms [15] although with a speech and conservative chore. Specially this coincides with the above mentioned for Gentleman (2001, p. 17) "the feminine identity is in transition as there it are the different rolls that the women are assuming along its course of life, understood like sequence and change, but at the same time like juxtaposition of stages and rolls." To the previous thing also one would add that the men or the masculine identity are in transition, because they are both who are facing and assuming new rolls, although to different rhythm.

For his part the grandparents males are already at present interfering in the domestic works, which can be due to the fact that they are in its stage of retirement in addition to which they are tired and sick for what to support its wife has served to them to stay busy. In the second generation, the woman works but the man interferes minimally in the domestic activities, the woman is satisfied with its role of mother, wife and worker. The third generation is supported in the traditional role for fear on the part of the woman to a rupture (separation) for the social and cultural weight that even relapses into them, although it is seen like a possibility in case of there was no entire understanding, in contrast to the men for who the separation is not considered since they prove to be satisfied before the serviceability that for them represents being married. The wives of the third generation are not fought with the idea of the divorce in contrast to the women of firstly and the second generation for whom at this point the separation is anything unthinkable.

\section{Egalitarian dealing in the relation}

The couples, often suppose that the equality between the genres has been already achieved. This illusion is founded on the resemblance of rolls of domestic extra work and on the possibility of 
autoabastecerse economically on the part of many women [15]. This fact observes that principally in the second generation where the women decide to rebel to go out after it works what has not implied necessary for them possibilities equality since the fact that they work it is not accompanied necessary by a major responsibility of the males in the domestic and affective rolls. This has generated a fundamental inequality that has usually led these women to the "double day of work", which they accept without any problem, since they recount that its priority first of all is its family and working they do it for taste, since in these cases they decide how they administer its money.

The problematic ones that are evident in the couple tie express the tension between the ideal of couple represented by the traditional marriage, in which the women are located in a dependent position with regard to the males, and the discomfort that the adjustment to the above mentioned ideal began to generate in the feminine population, to then go spreading, although in less measurement, the masculine population.

In this investigation, they have been and it is the wives of three generations who took the initiative to check its social place and the traditional models of femininity, which has created conflicts in its couple relation generating confusion to them with regard to the dealing that its couple gives to them, the distribution of tasks and care of the children.

At present, [15] recounts that the attitudes of the women opposite to the couple relation are diverse, as it is its attitude with regard to the form as the power is distributed between both parts. The more traditional is the model of reference, major it is the masculine predominance and, therefore, the less feminine autonomy.

The genre equality keeps on being an illusion because although in the culture at present the achievement of the equity is promoted it is in this study that in the first generation exists an entire mastery of the man over the woman, the woman questions its place but he does not say it that it remains in its relation because she feels socially forced, in the second generation these dissents begin going out and they are externadas for the woman to its couple, on having questioned for example: "Two or three occasions I allowed it to go with its friends to Acapulco, but later I said to myself, funny what, why he if it goes away and I not (Pepe's Mother)", but nevertheless he is the man who maintains its domain. Already in the third generation these questions appear again on the part of the woman only that do not know how to handle it, they try to defend themselves and demand by means of the violence, both men and women impo- se its ideas, causing conflict between them and coming finally to the blows "She puts more firewood to the fire" (Enrique).

In accordance with [16], the permanence of the women in relations in which violence one has lived is because there exists in the women a psychic commitment that leads them to wanting to expire with the project or order that has imposed the culture of what must be a woman: patience, good mother, somatizar, etc. In this case in all the couples the woman has been violentada for the male and specially in the third generation both have been attacked and nevertheless they remain.

Both men and women are before slightly clear situations to be related between themselves, but they are still before more ambiguous situations to define their own personal and social condition before social, proper prescriptions of its culture and the new generic practices. The built identities are suffering modifications, it is in particular the feminine identity the one that is in constant transition as there it are the different roles that the women are redeeming along the course of its life.

II. The genre identity: Femininity and masculinity in young couples that remain married.

It is important to dedicate a specific paragraph to the generation of young people because they are a report of the changes that they have come gestating years behind, they are they who are not being able to confront them to the interior of its relation, which if he does not manage of the best way can drive to a separation.

An important aspect to stand out in this generation is the one that one of the couples of this study decided in favor of the separation after several attempts for others maintained its marriage, nevertheless, two couples are still together in spite of feeling little satisfied with its marital relation. In these cases, the permanence in the marriage not necessary involves satisfied couples, as it mentions [3], because the divorce or separation is not an indicator of "marital unhappiness" since these couples in spite of showing unhappiness in its relations believe in the marriage and its kindness, because they worry for the economic and emotional effects associated with the rupture, and because they want to remain joined to give to its children a "familiar" hearth. The reasons for which the couples in this epoch remain in its marriage can be diverse, what yes is notable is its desire to keep on fighting because they are sure of it not because someone forces them to do it.

In these young couples it is possible to observe that the woman is more conscious than the changes that the male, the changes of 
identity of genre are more recognized or work for the woman, without meaning with it that they carry out it, which makes her to be placed in the progress (internally) and to the static man in its macho position. This can be related to what Navarrese (2004) says, that the masculinity and femininity are constructing themselves for the rigorous control imposed in the familiar and social conducts, from the childhood, what generates automatic mechanisms that inhibit its free and responsible actions for both genres.

The roles that men and women adopt are situations transmitted culturally. The man's role as an active provider and the woman like the manager of the upbringing of the children characterize the young couples of this study, find it hard to them work to get rid of something that has been accepted for years, which generates not alone conflict with its couple but with those who surround them and principally an internal conflict exists, specially in the woman a struggle is observed with itself that he does not allow her to be happy to be calm, that is to say, from the psychoanalysis [12] recounts that "the women not only must fight against the males to defend its new condition but, first of all, they must be debated by themselves" (p.68) even if the new conscience announces the progressive extinction of these old rules, the economic, sociocultural obstacles and especially psychic that him are opposed are powerful.

A difficult role of the woman is observed, he keeps back to suit with the society. Psychologically it is more affected, although the man shows less advance in the change. In this aspect the men correspond more to what they want and do, although it does not mean necessary an advance or adaptation to the new demands, but they show the comfort state. An important aspect to stand out in the male is that this one is visualized to side of its wife and children, for no motive he has chosen for the separation to comparison of the woman who in spite of resisting to the changes of the modernity sees like an option the divorce. It is necessary to highlight that in case of the couple that separated she was the woman who decided to move away and the male finally accepted, although it was not anything that it had in mind, this confirms the above mentioned for Hite [1] that now are the women those who ask for the divorce.

Before the conflicts between men and women there is added a feeling of incomprehension and a bad handling of the communication due to the confusion that generates the rolls game. There is conflict in how educating the children since the man wants to be part of its education and apparently the woman does not accept completely this approach.
It is excellent to emphasize that, in these couples of young people, the familiar tradition, social image, resignation and personal safety are present elements in the decision to remain married. It is understood then that so that a couple remains joined at present these three elements keep on having weight, even in the current youth, which become present in the intimate meeting of the relation of couple, in the domestic practices of its everyday life and in the shape of the identity of every member of the couple. It is necessary to indicate, following the proposals of Kaufmann (in Blemishes, 2006), that the couples will always remain like intimate strangers, with different combinations between the surprise and the intimacy along its history.

The central difference in the studied population takes root in its interest to maintain the relation, in these couples it highlights the commitment that exists between them. As Him and Agnew (2003) the commitment is the subjective experience of the dependence; of such form; the commitment is the psychological experience of this state. It is possible to be said that so that a relation should be compromised or lasts [17-28], the pros of the same one must be Superiors and wider than the contras, which is observed in these young couples because they have more positive motives for remaining together, one of them they are its children, although what they express is that to keep on sacrificing to maintain the relation. This allows to affirm that the culture prints forms typical of interaction on the couple meetings and therefore also of the family.

\section{Conclusions}

\section{Women}

- The woman tries to go out of its role of oppressed, which generates a struggle with it to the not externarlo, presents fear of the change.

- $\quad$ The seen in the marriage of parents and grandparents sows in the woman the suspicion to create new forms of interaction with its couple therefore it tends to repeat conduct patterns problems are avoided.

\section{Males}

- Generally the men are more satisfied than the woman with its marital relation because they feel more safe inside its marriage for which also it finds it hard to them work to leave aside some macho characteristics.

- The parenthood is important for the males, it worries them to be close to its children because they lacked this paternal figure. 
- Three Generations

- The couples remain still in spite of not feeling satisfied with its marriage. The dissatisfaction is externada only for the woman.

- The physical violence and verbal form part of the marital relation of the couples of this study which recounts the absence of communication on not having known how to handle the social changes in its daily life.

- Three generations present a conservative speech and with sights towards the progress which can be interpreted as a fear of the change, they are in internal conflict on not having known how to defend its interests without this implying a separation.

- Men and women try to accept the new social changes, but it is not simple to them for cultural and personal situations.

- The familiar Tradition, social image, resignation and personal safety are present elements in the decision to remain married in the generation of young people.

- $\quad$ The first and third generation they present marked similarities in the fact that the young people seems to have stepped back the time and to be supported in the traditional roles, the man works and the woman devotes herself to the hearth and children, like result of the experience at a hard-working and absent mother's.

\section{Bibliography}

1. Fonseca C and Quintero M. "Temas emergentes en los estudios de género". México. D.F.: Miguel Ángel Porrúa (2008).

2. Amato $\mathrm{P}$ and Hohmann-Marriott B. "A comparison of highand low-distress marriages that end in divorce". Journal of Marriage and Family 69.3 (2007): 621-638.

3. Tuirán R. "Familia y sociedad en el México contemporáneo" en Saber ver (1994): 33.

4. Burín M and Meler I. "Género y familia: poder, amor y sexualidad en la construcción de la subjetividad". Buenos Aires: Paidós (2001).

5. Donati. "Approccio morfogenetico vs teoria della strutturazione La crítica di M.S. Archer ad A. Giddens". Studi di Sociologia 3 (1999): 295-315.

6. Taylor and Bogdan. "Introducción a los métodos cualitativos de investigación". México: Paidos (1986).
7. González A and Castellanos B. "Sexualidad y Género. Una reconceptualización educativa en los umbrales del Tercer Milenio". (2), Bogotá: Magisterio (1996)

8. Ibañez L. "Laberintos de la feminidad: La decisión de no ser madres, estudio en un grupo de mujeres casadas". Tesis de Maestría: Universidad Autónoma del Estado de México (2014).

9. Bardwick J. "Psicología de la mujer: Un estudio de conflictos bioculturales". Madrid: Alianza editorial (1994).

10. Bonder G. "Patriarcado, familia nuclear y la constitución de la subjetividad femenina". Buenos Aires: Centros de estudios de la mujer (1982).

11. Rubin G. "El tráfico de mujeres: notas sobre la economía política del sexo". Nueva Antropología. 3.30 (2009).

12. Schnaith N. "Condición cultural de la diferencia psíquica entre los sexos”. en Lamas, M. y Saal, F (1998): 43-78.

13. Moore J. "Y qué pasa con los hombre". Santiago de Chile: Cuatro vientos (1994).

14. Lagarde M. "Género y feminismo. Desarrollo humano y democracia". Madrid: Horas y Horas (1998).

15. Castro I. "La pareja actual, Transición y cambios". Buenos Aires: Lugar Editorial (2004).

16. Lerma S. "Violencia contra la mujer: Desmentir, negar y justificar". Conferencia en México, Facultad de Ciencias de la conducta (2014)

17. Torres T and Ojeda A. "El compromiso y la estabilidad en la pareja: definición y dimensiones dentro de la población Mexicana". Psicología Iberoamericana 17.1 (2009): 38-47.

18. Bleichmar E. “El feminismo espontáneo de la hysteria”. México: Fontamara (1997).

19. Bock J. "La historia de las mujeres y la historia del género: aspectos de un debate internacional”. Valencia: Instituto de Historia social (1991).

20. Caballero M. "Abuelas, madres nietas. Generaciones y vida laboral en el México Urbano". Universidad Autónoma del Estado de México (2001).

21. INEGI. Anuario estadístico de los Estados Unidos Mexicanos (2011). 
22. Le B and Agnew C. "Commitment and its Th eorized Determinants: A Meta-Analysis of the Investment Model". Personal Relationships (2003): 37-57.

23. Mancillas C. "La construcción de la intimidad en las relaciones de pareja: el caso de valle de chalco". Psicología Iberoamericana 14.2 (2006): 5-15.

24. Méndez C. "Metodología: Diseño y desarrollo del proceso de Investigación". Colombia: Mc Graw Hill (2001).

25. Navarro R. "Mujeres Mexicanas que sufren y aman demasiado". México: Pax (2004).

26. Tarres M. "Observar, escuchar y comprender: sobre la tradición cualitativa en la investigación social". México: Colegio de México (2001).

27. Zarza S. “¿Masculinidad y Feminidad en crisis? Investigación en dos generaciones de hombres y mujeres, desde una perspectiva de género. Memorias del Coloquio de investigación". Toluca: UAEM (2008)

28. Zarza S. “Escala de Identidad de Género”. Toluca: UAEM (2012).

Volume 2 Issue 10 October 2019

(C) All rights are reserved by Anirian de los Ángeles

Esquila Ambriz., et al. 